\title{
The concept of 'cultural landscapes' in relation to the historic port town of Tomo
}

\author{
Kazuo Mouri \\ Institute of Port-Town Culture in Setouchi
}

\section{Introduction}

In 1992 the UNESCO World Heritage Committee adopted a new category of World Heritage, 'Cultural Landscapes', in order to recognise and protect environments that are 'illustrative of the evolution of human society and settlement over time, under the influence of the physical constraints and/or opportunities presented by their natural environment and of successive social,

How to cite this book chapter:

Mouri, K 2016 The concept of 'cultural landscapes' in relation to the historic port town of Tomo. In: Matsuda, A and Mengoni, L E (eds.) Reconsidering Cultural Heritage in East Asia, Pp. 121-138. London: Ubiquity Press. DOI: http://dx.doi.org/10.5334/baz.g. License: CC-BY 4.0 
economic and cultural forces, both external and internal' (UNESCO World Heritage Centre: Article 47). Following this example, in 2004 Japan revised its Law for the Protection of Cultural Properties to include the protection of bunkateki keikan, a term directly translated from the English 'cultural landscapes'. Although many similarities can be seen between Cultural Landscapes defined by UNESCO and bunkateki keikan falling under the Japanese law, there are also significant differences, which are largely due to the existence of other related categories of cultural properties in Japan.

Bearing this in mind, the present chapter examines the recent dispute regarding the proposed construction of a bridge over the bay of the historic port town of Tomo (also known as Tomonoura), in Fukuyama City, Hiroshima Prefecture. The aim of this examination is to consider how different categories of cultural properties can, or cannot, apply for the protection of cultural landscape in Tomo.

\section{Legal structures for the protection of cultural landscapes in Japan}

It would be useful to first give an overview of the Japanese legal structures relating to the protection of cultural landscapes. In Japan, the protection of cultural heritage mostly falls within the Law for the Protection of Cultural Properties, which was enacted in 1950 and has since gone through several amendments (Agency for Cultural Affairs 2001). In considering the protection of cultural landscapes, three categories of cultural properties defined in the present Law are relevant.

\section{Bunkateki keikan}

The first category to consider is bunkateki keikan, which literally means 'cultural landscapes'. The Law for the Protection of 
Cultural Properties defines bunkateki keikan as 'landscapes that have evolved in association with the modes of life or livelihoods of the people and geo-cultural features of a region, and which are indispensable to understanding the lifestyles and/or livelihoods of the people of Japan' (Article 2, Item 5).

Bunkateki keikan are in part related to UNESCO's Cultural Landscapes. UNESCO's Operational Guidelines for the Implementation of the World Heritage Convention defines Cultural Landscapes as representing 'the combined works of nature and of man' (UNESCO World Heritage Centre 2013: Article 47) and sets out three categories: 1) 'clearly defined landscape designed and created intentionally by man'; 2) 'organically evolved landscape'; and 3) 'associative cultural landscape' (UNESCO World Heritage Centre 2013: Annex 3, Article 10). The Guidelines divide the second category 'organically evolved landscape' further into 'relict (or fossil) landscape', in which 'an evolutionary process came to an end at some time in the past', and 'continuing landscape', which retain 'an active social role in contemporary society closely associated with the traditional way of life, and in which the evolutionary process is still in progress. Of these categories and sub-categories of UNESCO's Cultural Landscapes, 'continuing landscapes' and 'associative cultural landscapes' are related to Japanese bunkateki keikan (Table 1).

What is worthy of note here is that bunkateki keikan does not cover the 'landscapes of the past, where no present residents maintain the modes of life or livelihood activities' that originally contributed to their formation (Edani 2012: 3), and as such cannot include 'relict/fossil landscapes' as defined by UNESCO. This means that bunkateki keikan, in comparison with UNESCO's Cultural Landscapes, places greater emphasis on the continuity of activities associated with the concerned landscapes by the local population. This characteristic is also noticeable in the eight types 


\begin{tabular}{|c|c|c|}
\hline \multicolumn{2}{|c|}{$\begin{array}{l}\text { UNESCO's Operational Guidelines } \\
\text { for the Implementation of the World } \\
\text { Heritage Convention ( } 2013 \text { version) }\end{array}$} & $\begin{array}{l}\text { Related categories of Japanese } \\
\text { cultural properties as defined } \\
\text { in the Law for the Protection of } \\
\text { Cultural Properties }\end{array}$ \\
\hline \multicolumn{2}{|c|}{$\begin{array}{l}\text { Clearly defined landscape designed and } \\
\text { created intentionally by man }\end{array}$} & Mainly meishô \\
\hline \multirow{2}{*}{$\begin{array}{l}\text { Organically evolved } \\
\text { landscape }\end{array}$} & $\begin{array}{l}\text { Relict (or fossil) } \\
\text { landscape }\end{array}$ & Mainly meishô \\
\hline & $\begin{array}{l}\text { Continuing } \\
\text { landscape }\end{array}$ & $\begin{array}{l}\text { Mainly bunkateki keikan, } \\
\text { and potentially also dentôteki } \\
\text { kenzôbutsugun hozon chiku }\end{array}$ \\
\hline \multicolumn{2}{|c|}{ Associative cultural landscape } & $\begin{array}{l}\text { In part bunkateki keikan, and in } \\
\text { part meishô }\end{array}$ \\
\hline
\end{tabular}

Table 1: Relation between the categories of UNESCO's Cultural Landscape and the related categories of cultural properties in the Japanese Law for the Protection of Cultural Properties.

of bunkateki keikan set out by the Japanese Ministry of Education, Culture, Sports, Science and Technology:

- Places related to agriculture, such as rice paddies and farmland.

- Reed plains used for harvesting grass, and pastures used for grazing livestock.

- Forests, such as timber forests and disaster prevention forests.

- Places related to aquaculture, such as fisheries and seaweed fields.

- Places involving the use of water, such as reservoirs, waterways and ports.

- Places related to mining and industry, such as mines, quarries, and factories. 
- Places related to transportation and communication, such as roads and plazas.

- Places associated with dwellings, such as fences and coppices.

(Ministry of Education, Culture, Sports, Science and Technology 2005: Notice No.47)

These eight types of place relate to primary industries involving farming, forests and water and secondary and tertiary industries closely associated with the land. Importantly, all of these industries are supposed to actively continue to date. It is interesting to note that even urban landscapes can be designated as bunkateki keikan, as far as there is continuity of the associated livelihoods of local people.

The process for designating bunkateki keikan has two stages. First, municipal governments decide on their local cultural landscapes to be protected and accordingly set out plans to safeguard them. Thereafter, at the request of the municipal governments, the Ministry of Education, Culture, Sports, Science and Technology assesses and designates these locally protected landscapes as jûyô bunkateki keikan (meaning 'important cultural landscape') to give them national level protection.

\section{Meishô}

Although 'relict/fossil landscapes' cannot be designated as bunkateki keikan, they could be protected as meishô as defined by the Law for the Protection of Cultural Properties. Meishô is closely associated with traditional Japanese concepts of appreciating places, such as meisho, kyûseki and utamakura, and refers in particular to places of scenic beauty. While the concept of meishô 
existed even before the establishment of the modern state of Japan and the concomitant institutionalisation of legal structures for protecting cultural properties, it was only towards the end of the Meiji period that meishô came to be considered under threat of destruction (Watanabe 2006: 74). During the Meiji period, Japan aimed to compete politically and economically with the Western powers, and accordingly rushed to open up land, build new roads, lay down railway lines and construct large-scale factories. The 1919 Law for the Preservation of Historical Sites, Places of Scenic Beauty and Natural Monuments was enacted as a response to this situation; the meishô designated by this law were given legal protection for the first time. In 1950, the 1919 Law was integrated into the newly established Law for the Protection of Cultural Properties, and meishô became a category of cultural properties under the group of shiseki meishô tennenkinenbutsu (historic sites, places of scenic beauty and natural monuments).

According to the present Law for the Protection of Cultural Properties, a place can be designated as a meishô if it is 'an indispensable place due to the superior beauty of its terrain' (Ministry of Education 1995: Notice No.24). This designation can cover both natural places and places related to human activities. To make the criterion for designation more precise, the Ministry of Education (1995: Notice No.24) set out eleven different types of meishô, which are: (1) parks and gardens; (2) bridges and embankments; (3) places with flowering trees, grasses and other foliage; (4) locations of wildlife, fish and insects; (5) rocks and caves; (6) canyons, waterfalls, mountain streams and ravines; (7) lakes, wetlands, floating islands and spring fountains; (8) dunes, sandbars, beaches and islands; (10) volcanos and hot springs; and (11) vantage points. Importantly, whether a place can be designated as a meishô is largely based on aesthetic judgement, which means that 
the livelihood of local people and their relationship to the place are not taken into consideration (Hirasawa 2009: 102-103).

Of the three categories of UNESCO's Cultural Landscapes shown earlier, meishô are related to 'clearly defined landscapes designed and created intentionally by man', such as gardens and parks, 'relict/fossil landscapes', and some of the 'associative cultural landscapes', especially those having religious and/or artistic associations (Table 1).

\section{Dentôteki kenzôbutsugun hozon chiku}

Another category of Japanese cultural properties that is relevant to the protection of cultural landscapes is dentôteki kenzôbutsugun hozon chiku, or preservation districts for groups of traditional buildings.

After the Second World War, despite the enactment of the Law for the Protection of Cultural Properties in 1950, the strategic drive towards post-war recovery by means of rapid economic growth resulted in the loss of much historic environment. Acknowledgement of the extent of this loss led in 1975 to the amendment of the Law for the Protection of Cultural Properties to form a system for protecting dentôteki kenzôbutsugun (groups of traditional buildings), which is still valid today.

Dentôteki kenzôbutsugun hozon chiku differs from bunkateki keikan in that it consists of a concentrated cluster of historic buildings, and as such cannot be applied to an area where there is no historical building and to a vast area where historic buildings exist but are dispersed and do not form an architectural cluster. For example, rice paddies and farmland cannot be designated as dentôteki kenzôbutsugun hozon chiku, although they may be protected as bunkateki keikan. 
The process of designating dentôteki kenzôbutsugun hozon chiku is similar to that of designating bunkateki keikan. First, municipal governments designate their local preservation districts according to their own criteria, by-laws and management plans. Thereafter, the Ministry of Education, Culture, Sports, Science and Technology, at the request of the municipal governments, assesses and designates these local preservation districts as jûyô dentôteki kenzôbutsugun hozon chiku (important preservation districts for groups of traditional buildings) to give them national level protection.

The above review of the three categories of cultural properties clearly demonstrates that the idea of protecting cultural landscapes did exist in Japan, albeit with some limited extent, even before the adoption of the category bunkateki keikan in the Law for the Protection of Cultural Properties in 2004. This fact should be stressed, as it is sometimes overlooked because of the understanding that bunkateki keikan is a relatively new, imported term and concept. As seen above, there have been legal mechanisms to protect groups of historic buildings as dentôteki kenzôbutsugun hozon chiku since 1975, and places of scenic beauty as meishô since 1919. In this sense, the adoption of bunkateki keikan should be understood as a means to expand the coverage of protection of cultural landscapes in Japan. With this in mind, let us now examine the case of the protection of cultural landscape in Tomo.

\section{The historic port town of Tomo}

Tomo's position on the coast of Honshu facing Shikoku places it within the central area of the Seto Inland Sea (Figure 1). Until the development of the steamship, Japanese ships relied on wind and 


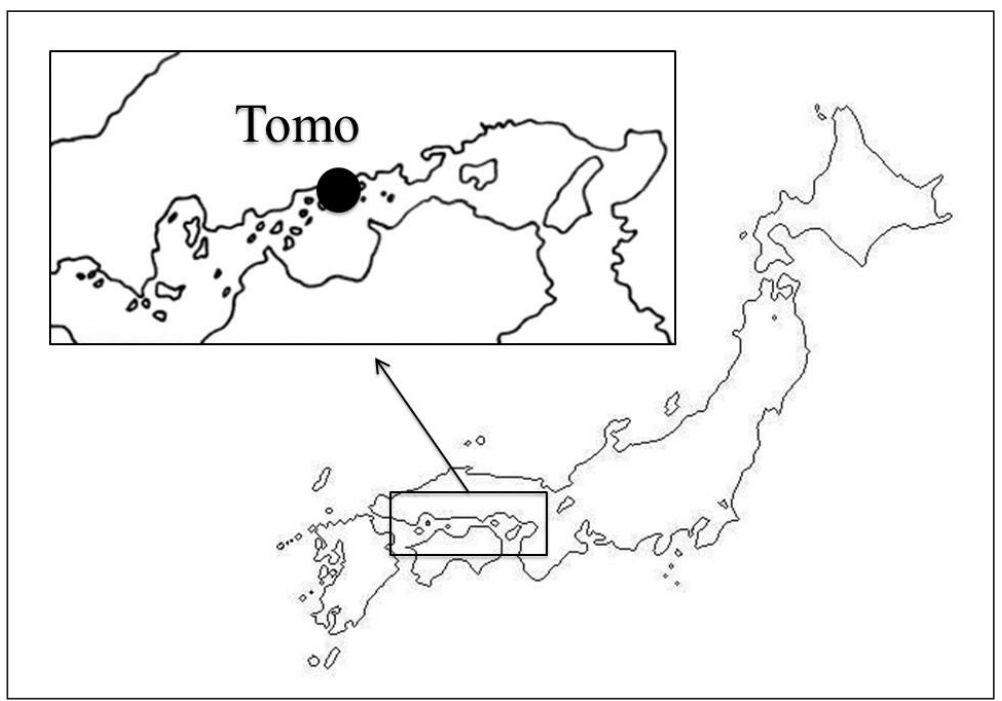

Figure 1: Tomo's location in the Japanese archipelago and the Seto Inland Sea (upper box) (map design by Akira Matsuda).

tide for power, and ports were therefore sited in places like Tomo where it was convenient to wait for the changing of the tides. Located on a small bay about 500 metres across, backed by mountains and with many islands nearby, Tomo's geographical situation was ideally suited to the commercial activity of a port town.

The historic town of Tomo that we see today came into being during the first half of the 19th-century, although its origins go back much earlier. The town appears in the Man'yôsh $\hat{u}$ (Collection of Ten Thousand Leaves), an official poetry collection compiled during the 8th-century, when the ancient Japanese state was consolidated. The author of one poem (Book 3, 0446) was a courtier appointed to set up a diplomatic post in a province of Kyushu, the southern gateway to Japan. He and his wife travelled there together, visiting Tomo on the way. The courtier's wife died during his tenure, however, and on the journey back to the capital he 
returned to Tomo where, as he describes in the poem, he stood alone staring at a tree, lamenting his loss.

During the Edo period (1603-1868), under the rule of the Tokugawa Shogunate, the Korean Joseon Dynasty dispatched a diplomatic mission to offer congratulations each time a new shogun was appointed. According to the Nittô daiichi keishô (The Finest Landscapes of the East), in 1711 the eighth such mission stopped at a guesthouse in an historic temple in Tomo on its journey back to Korea. When asked to name the most beautiful place between Edo and Tsushima, the mission replied that it was Tomo.

During the same Edo period a shipping route was opened from the northeast provinces, down to the coast of the Sea of Japan/ East Sea, and then via the Seto Inland Sea up to Osaka. Kitamaebune, north-bound ships, transported goods along the route and trade grew. As the Japanese economy prospered, Tomo flourished, reaching a peak in the mid-19th-century. Today, Tomo is the only place in Japan that maintains a complete set of the five fixtures that a port needed in order to function during the Edo period (The Sixth Subcommittee of the Japan ICOMOS 2007: 1-4): jôyatô (a large lantern on a high stand serving as a lighthouse); gangi (a stepped embankment where a ship could be hauled out of the sea and drained of seawater); funabansho (a marine warden's office); namidome (a breakwater); and tateba (a dry dock for ship maintenance).

Contemporary society may recognise Tomo as the hometown of the anime character Ponyo, known to many through the movie Ponyo on the Cliff by the Sea (Gake no ue no Ponyo) produced in 2008 by the internationally renowned film director Hayao Miyazaki. Tomo shaped Ponyo's conception, and various sites in the town appeared in scenes throughout the film, including streets 
and neighbourhoods built during the Edo period, which contributed to the rise of popularity of Tomo's landscape nationwide.

Certain aspects of Tomo's landscape have been under legal protection for several decades. In 1925, the small islands near the port that have traditionally been the subject of aesthetic appreciation to be viewed from Tomo were designated as a meishô under the 1919 law, and in 1934, a wide area of the Seto Inland Sea was designated as a national park, under the name of Setonaikai National Park. Both designations are still valid today. In addition, in 2008 Fukuyama City designated an 8.6 hectare $(21.25$ acre) area of the historic quarter of Tomo as a dentôteki kenzôbutsugun hozon chiku (preservation district for groups of traditional buildings). The area incorporates 102 buildings from the Edo period, 85 buildings from the Meiji period (1868-1912) and 270 traditional buildings constructed before the Second World War (Mouri 2011: 5). It is important to note that this designation protects a particular cluster of buildings without taking a broader view of their geographical context, and thus excludes some of the key port facilities. As of spring 2015, this dentôteki kenzôbutsugun hozon chiku still remains a local designation and has yet to receive national level protection.

\section{Dispute regarding the plans to build a traffic bridge on reclaimed land at Tomo}

Traffic flow in Tomo has long been a critical issue in relation to both economic development and historic preservation. Since the main road was only four meters wide (Figure 2), large vehicles were not able to drive there and even smaller cars were dangerously close when they passed. In 1983, Hiroshima Prefectural Government put forward plans to alleviate the problem 


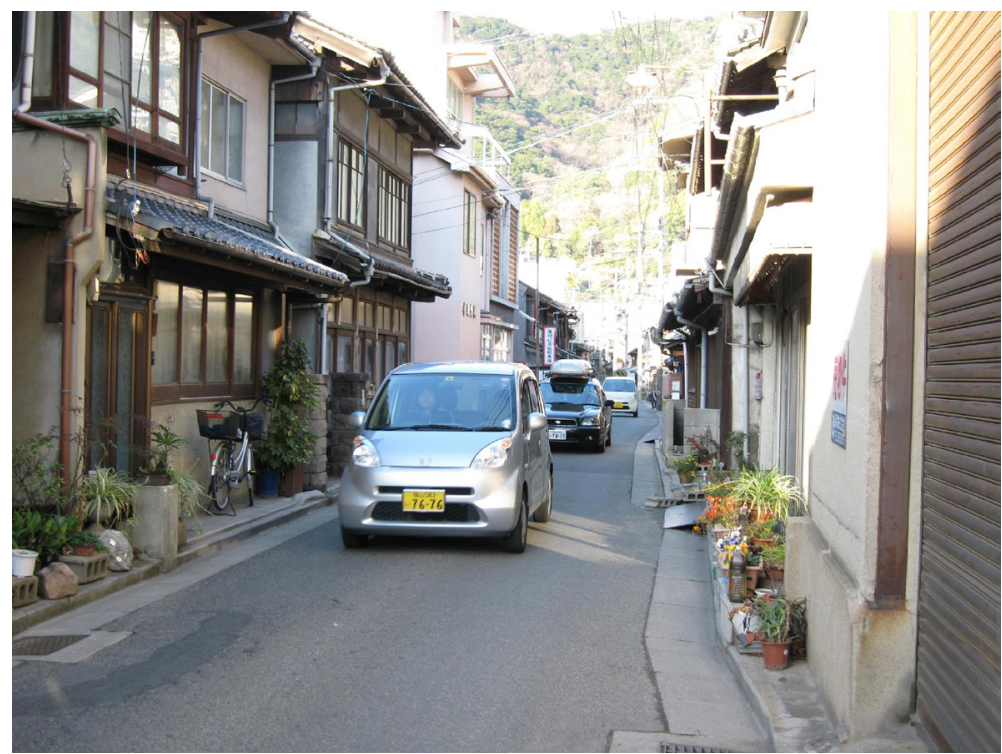

Figure 2: The main road in Tomo, which is only about four metres wide (photo by Akira Matsuda)

by constructing a bridge on reclaimed land in the historic port. While the bridge was intended primarily to improve the living conditions of local residents, rather than to achieve large-scale economic development, the impact of its construction became a focus for the endemic tension between the town's economic growth and historic preservation, highlighting the difficulty of operating within the legislative framework for the protection of Tomo's unique cultural landscape. If construction of the bridge had gone ahead, large vehicles that until then had been unable to enter Tomo would have been routed through the town, inevitably affecting its historic landscape and potentially endangering its residents. A number of local residents protested against the plans and initiated a lawsuit demanding that permission for land 
reclamation be denied on the basis that it would compromise the scenery of the port.

In the lawsuit, the plaintiffs, residents of Tomo, claimed that the whole environment of Tomo measuring 1,779 ha (4,396 acres) should be carefully taken into consideration in town planning, and special attention should be paid to the landscape of the historic centre, including the historic port (43 ha or 106.3 acres) and the combined district of historic streets and buildings, temples and shrines (35 ha or 86.5 acres). These residents argued that no approval should be given for works that would significantly detract from this landscape (Mouri 2011: 5).

In response, the defendant, Hiroshima Prefectural Government, claimed that there was no problem with the works as long as they were not carried out in the area designated as a meishô according to the Law for the Protection of Cultural Properties. Here it should be remembered that this meishô area does not include the port area but only the small islands surrounding Tomo. Hiroshima Prefectural Government also argued that the project would not infringe on any regulations for the management of the Setonaikai National Park, which includes Tomo and its surrounding sea but gives them only the weakest level of protection. On this basis, Hiroshima Prefectural Government maintained that the reclamation and construction project should go ahead because it would not affect the historical neighbourhoods and 'five fixtures' of the port, thus showing enough care for the preservation of cultural heritage within the proposed project.

The lawsuit, which attracted nationwide interest, resulted in a historic outcome. On October 1, 2009 the Hiroshima District Court found in favour of the plaintiffs and blocked permission for the Hiroshima Prefectural Government to proceed with the 
project (Mouri 2011: 5). For the first time ever in Japan, the courts refused to grant a public works permit on the grounds that the works would damage an historic landscape. The ruling concluded that Tomo's scenery has historical and cultural value and serves the public good. The official verdict stated:

'Tomo Port offers a splendid view of the peaceful waters of the Inland Sea and the islands floating within it. This view along with the scenery of the port itself - that is to say, its crescent-shaped coastline, its breakwaters jutting out into the sea, its stepped piers built along the quays, its night-lights lingering in the middle of the port, the remains of its ship guard station on the hill ... in combination with old streets and neighbourhoods and buildings associated with historical events - as a whole forms a beautiful scenery ... The port facilities... and the old streets, neighbourhoods and buildings tell the story of Tomo, which flourished for many years as a port town and have been the stage of historical events and of the economic, political and cultural activities of a great many people. From this point of view, it can be argued that the above-mentioned scenery is not merely valuable for its beautiful townscape but has historical and cultural value in its entirety as well'.

Although the verdict did not use the term 'cultural landscape', many aspects of it were in agreement with the concept of a 'Cultural Landscape' as defined by UNESCO, and in particular, its category of 'continuing landscape'.

Hiroshima Prefectural Government objected to the court decision and submitted an appeal. However, in June 2012, Mr Yuzaki Hidehiko, Governor of Hiroshima Prefecture elected in November 2009 , announced the withdrawal of the 30-year-old plans for the construction of a bridge and instead proposed to dig a tunnel 
through the mountains behind the town and introduce a parkand-ride policy to alleviate the traffic problem. By stopping cars from entering the town, the Governor argued, the change in town planning policy would provide safer traffic and better living conditions for residents whilst also protecting the historic landscape. This new proposal has, however, yet to be officially accepted at the time of writing (spring 2015) due to the opposition of certain stakeholders and the concerns about the implications of the new construction work to be entailed.

While the ruling of the Hiroshima District Court and the subsequent decision by Governor Yuzaki to withdraw the plans to construct a bridge on reclaimed land was ground-breaking and suggested that the protection of cultural landscape would become a more important agenda in town planning in Japan, it also marked the beginning of a new challenge in Tomo, which was to ensure long-term protection of the town's historic landscape.

As of spring 2015, Fukuyama City does not consider the option of protecting Tomo's port landscape with the designation of bunkateki keikan. This seems largely due to the foreseeable great challenge of obtaining agreement from all the stakeholders, in particular those whose land use would be restricted by such designation. The possibility of the designation of bunkateki keikan itself will, however, remain as an option to be taken in the future.

A less difficult option, at least in theory, would be to raise the current local designation of dentôteki kenzôbutsugun hozon chiku (preservation district for groups of traditional buildings) to the national level designation of jûyô dentôteki kenzôbutsugun hozon chiku (important preservation district for groups of traditional buildings). As already stated, however, this has not materialised to date, despite Fukuyama City's intention to achieve it sooner. 
One reason of the delay is that the national Agency for Cultural Affairs, which reports to the Ministry of Education, Culture, Sports, Science and Technology, is not convinced yet whether the area for protection currently set in the local designation is adequate. In 2010, the Agency for Cultural Affairs advised Fukuyama City to examine whether the designated area was not too small, and Fukuyama City has since been working on it, considering whether or not to include the ancient zone that houses historic temples and shrines (teramachi). What makes the situation complicated, however, is that the local designation had been made on the assumption that the bridge over the bay would eventually be constructed. With the bridge construction suspended indefinitely, the residents of the historical quarter have been left uncertain as to whether their living conditions could be brought up to the standards of modern society under the even tighter national level protection.

\section{Conclusion}

In Japan, certain forms of cultural landscape were protected as meishô and dentôteki kenzôbutsugun hozon chiku already before the adoption of the category bunkateki keikan in the Law for the Protection of Cultural Properties in 2004. The adoption of bunkateki keikan, however, contributed to the expansion of the scope of protection of cultural landscape, and as a result the landscapes that have developed in close association with the modes of life and livelihood of the local population came under legal protection.

Against this background of increased interest in the protection of cultural landscapes nationwide, the Hiroshima District Court ruled against the construction of a bridge over the bay of Tomo's port in October 2009, on the grounds that the town's historic 
landscape was valuable as a public good and therefore deserved protection. This ground-breaking ruling led Hiroshima Prefecture Government to suspend the construction of the bridge indefinitely, and Tomo has since been tackling the new challenge to find an appropriate mechanism for the long-term protection of its port landscape. Elevating the currently local designation of dentôteki kenzôbutsugun hozon chiku to the national level designation would probably be the first task in this challenge. Considering the need to safeguard the wider port landscape as well as to achieve sustainable development in the town, designating the Tomo's whole historic landscape associated with local people's livelihood as a bunkateki keikan might be necessary in the long term.

\section{References}

Agency for Cultural Affairs 2001 Bunkazai Hogohô Gojûnenshi (The Fifty Year Old History of the Law for the Protection of Cultural Properties). Tokyo: Gyosei.

Edani, H 2012 Conservation and Management of Cultural Landscapes. Nara National Research Institute for Cultural Properties. http://www.nara.accu.or.jp/elearning/2012/conservation. pdf (accessed on 1 September 2015).

Hirasawa, T 2009 Bunkazai To Shiteno Bunkateki Keikan No Haaku Rikai Hyôka No Tameno Shiten To Chôsa Kenkyû No Hôkôsei Ni Tsuite (Perspectives for the Understanding and Evaluation of Cultural Landscapes as Cultural Properties and the Direction of Future Research). In: Bunkateki Keikan Kenkyû Syûkai Daiikkai Hôkokusyo (Report from the First Research Conference on Cultural Landscapes). Nara: Nara National Research Institute for Cultural Properties. pp. 96-122.

Mitchell, N, Rössler, M and Tricaud, P (eds.) 2009 World Heritage Cultural Landscapes: A Handbook for Conservation and Management. Paris: UNESCO. 
Mouri, K 2011 Ryôkôna Keikan No Keisei To Kankôryoku (Formulation of Good Landscape and Tourism Power). The Archaeological Journal (Kôkogaku Jânaru), 609: 4-8.

The Sixth Subcommittee of the Japan ICOMOS 2007 Rekishiteki Kôwan Toshi 'Tomo No Ura': Bunkaisan Hogo Ni Kakawaru Chôsa Kenkyûu Hôkokusho (Historical Port Town 'Tomo no ura': Research Report for the Protection of its Cultural Heritage), http:www.japan-icomos.org/workgroup06/ 1stICOMOSReportText.pdf (accessed on 1 September 2015).

UNESCO World Heritage Centre 2013 Operational Guidelines for the Implementation of the World Heritage Convention. http:// whc.unesco.org/archive/opguide13-en.pdf (accessed on 1 September 2015).

Watanabe, A 2006 The Japanese System for Safeguarding Cultural Heritage. In: UNESCO (ed.) Proceedings of the International Conference on the Safeguarding of Tangible and Intangible Cultural Heritage: Towards an Integrated Approach. UNESCO, Paris: UNESCO. pp. 74-97. 